\title{
Tinjauan Pencapaian Otonomi Daerah Berdasarkan Kinerja Keuangan di Provinsi Nusa Tenggara Timur
}

\author{
Natalia Wuda, Norman Duma Sitinjak \\ Universitas Merdeka Malang \\ * Korespondensi noma1274@yahoo.com
}

Diserahkan: 18 November 2017, Direvisi: 4 Pebruari 2018, Diterima: 15 Pebruari 2018

\begin{abstract}
This study analyzes the financial performance of East Nusa Tenggara Province in terms of independence, effectiveness and efficiency. This research is qualitative descriptive type. The data used is secondary data, in the form of financial data of East Nusa Tenggara province in 2012 - 2016. From the research result, it is known that the level of financial independence and effectiveness level from 2012 until 2015 experienced a positive thing, the level of independence is increasing and the effectiveness of achievement Local Original Revenue targets are more than targeted. The efficiency level from 2012 to 2016 is not yet efficient.
\end{abstract}

Keywords: independence, effectiveness, efficiency.

\begin{abstract}
abstrak
Penelitian ini menganalisis kinerja keuangan Provinsi Nusa Tenggara Timur dari segi kemandirian, efektivitas dan efisiensi. Penelitian ini berjenis deskriptif kualitatif. Data yang digunakan adalah data sekunder, berupa data keuangan provinsi Nusa Tenggara Timur tahun 2012 - 2016. Dari hasil penelitian, diketahui bahwa tingkat kemandirian keuangan dan tingkat efektivitas dari tahun 2012 sampai dengan tahun 2015 mengalami hal yang positif, tingkat kemandirian terus meningkat dan efektivitas pencapaian target Pendapatan Asli Daerah melebihi yang ditargetkan. Tingkat efisiensi sejak tahun 2012 sampai dengan 2016 belum efisien.
\end{abstract}

Kata kunci: kemandirian, efektivitas, efisiensi.

\section{A. PENDAHULUAN}

Untuk mempercepat dan melakukan pemerataan pembangunan di daerah maka otonomi daerah perlu dilakukan. Tujuannya adalah agar pertumbuhan tidak hanya terpusat di wilayah tertentu saja tetapi merata ke seluruh wilayah Indonesia, sehingga kesejahteraan rakyat juga merata di setiap wilayah (Sitinjak, N. D, 2016). Sejak dimulainya Otonomi daerah, penyelenggaraan Pemerintah Daerah dilaksanakan secara mandiri baik oleh Pemerintah Daerah Tingkat I dan Pemerintah daerah Tingkat II. Kemandirian disini termasuk dalam pengelolaan keuangan. Dari faktor keuangan inilah dapat dinilai apakah suatu Pemerintah daerah sudah mampu menjalankan pemerintahannya secara mandiri, walaupun dana dari Pemerintah Pusat tetap diperlukan untuk membantu percepatan pelaksanaan pembangunan di daerah. Seperti yang disampaikan oleh Halim (2007) bahwa ciri kesuksesan pelaksanaan otonomi daerah adalah: 1) Kemampuan keuangan daerah, maksudnya adalah daerah berwenang, mampu menggali, mengelola keuangannya sendiri dengan cukup memadai sehingga mampu membiayai penyelenggaraan pemerintahannya, dan 2) Ketergantungan kePendapatan Asli Daeraha bantuan Pemerintah Pusat yang seminimal mungkin sehingga Pendapatan Asli Daerah (PAD) menjadi bagian sumber keuangan utama Pemerintah Daerah.

Semua Provinsi di Indonesia termasuk Provinsi Nusa Tenggara Timur diharapkan dapat menjalankan otonominya dengan baik sampai kePendapatan Asli Daeraha penggalian sumber keuangan dan pengelolaannya. Dengan demikian percepatan pembangunan di daerah dapat dilakukan. Setiap proses perlu diukur sehingga dapat diketahui kinerjanya 
dan upaya apa yang selanjutnya harus dilakukan agar dapat memberikan kontibusi yang nyata kepada masyarakat sekitar (Purbowati, R., \& Mutiarni, R, 2017).

Untuk mengukur sejauh mana pencapaian otonomi daerah Provinsi Nusa Tenggara Timur maka diperlukan pengukuran. Pengukuran kinerja keuangan dapat dijadikan sebagai tolak ukur untuk peningkatan kinerja khususnya keuangan pemerintah daerah Pendapatan Asli Daeraha periode berikutnya (Utomo, L. P., Asyik, N. F., \& Hermanto, S. B, 2017). Beberapa ukuran yang dapat digunakan ialah Rasio Kemandirian, Rasio Evektifitas, dan Rasio Efisiensi. Rasio kemandirian keuangan daerah untuk mengukur kemampuan Pemerintah Daerah dalam membiayai sendiri kegiatan pemerintahan, pembangunan, dan pelayanan kePendapatan Asli Daeraha masyarakat. Rasio Evektifitas untuk mengukur kemampuan Pemerintah Daerah dalam merealisasikan Pendapatan Asli Daerah yang direncanakan. Rasio Efisiensi Keuangan Daerah untuk mengukur kemampuan Pemerintah Daerah tentang pengeluaran dalam memperoleh pendapatan.

\section{B. KAJIAN PUSTAKA Otonomi Daerah}

Menurut Undang-Undang No.32 tahun 2004 pasal 1, Otonomi daerah merupakan kewenangan daerah otonom untuk mengatur dan mengurus kepentingan masyarakat setempat menurut prakarsa sendiri berdasarkan aspirasi masyarakat, sesuai dengan peraturan perundang-undangan. Daerah otonom adalah kesatuan masyarakat hukum yang mempunyai batas daerah tertentu berwenang mengatur dan mengurus kepentingan masyarakat setempat menurut prakarsa sendiri berdasarkan aspirasi masyarakat dalam ikatan Negara Kesatuan Republik Indonesia. Tujuan otonomi daerah adalah mencapai efektivitas dan efisiensi dalam pelayanan kePendapatan Asli Daeraha masyarakat di daerah.

\section{Pemerintahan Daerah}

Tentang kelembagaan, menurut Undang-Undang Nomor 32 Tahun 2004 Pemerintahan Daerah adalah penyelenggaraan urusan pemerintahan oleh pemerintah daerah dan DPRD menurut asas otonomi dan tugas pembantuan dengan prinsip otonomi seluas-luasnya dalam sistem dan prinsip Negara Kesatuan Republik Indonesia sebagaimana dimaksud dalam Undang-Undang Dasar Negara Republik Negara Tahun 1945. Tentang penyelenggaranya, menurut Undang-Undang Nomor 23 Tahun 2014 Pemerintah daerah dipimpin oleh kepala daerah sebagai unsur penyelenggara Pemerintahan Daerah yang memimpin pelaksanaan urusan pemerintahan yang menjadi kewenangan daerah otonom.

\section{Laporan Keuangan Pemerintah Daerah}

Sebagai bentuk pertanggungjawaban, pemerintah daerah harus membuat laporan keuangan Pemerintah Daearah. Hal ini dijelaskan melalui Peraturan Pemerintah Nomor 71 Tahun 2010 yang juga menjelaskan teentang peranan serta tujuan dari laporan keuangan pemerintah, dimana setiap entitas mempunyai kewajiban untuk melaporkan upaya-upaya yang telah dilakukan serta hasil yang dicapai dalam pelaksanaan kegiatan secara sistematis dan terstruktur Pendapatan Asli Daeraha suatu periode pelaporan.

\section{Analisis Kinerja Keuangan Daerah}

Setiap Pemerintah Daerah untuk mengukur Kinerja Keuangan Daerahnya menggunakan beberapa Rasio Kinerja Keuangan Daerah yang antara lain : 


\section{Rasio Kemandirian Keuangan Dearah (RKKD)}

Rasio ini untuk mengukur tingkat kemandirian suatu daerah dalam pembiayaan kegiatan pemerintah, pembangunan dan pelayanan kePendapatan Asli Daeraha masyarakat. Rumusnya sebagai berikut:

$$
\text { RKKD }=\frac{\text { PAD }}{\text { Pendapatan Transfer }} \times 100 \%
$$

Sumber : Halim ( 2007)

Semakin besar hasilnya berarti ketergantungan PEMERINTAH DAERAH terhadap Pemerintah Pusat semakin kecil dan sekaligus menunjukkan tingkat partisipasi masyarakat dalam membangun daerah semakin besar.

Indikator kemandirian daerah sebagai berikut:

Tabel 1: Tingkat Kemandirian Daerah

\begin{tabular}{lcc}
\hline \hline \multicolumn{1}{c}{ Kemampuan Keuangan } & Kemandirian & Pola Hubungan \\
\hline \hline Rendah Sekali & $0 \%-25 \%$ & Instruktif \\
Rendah & $25 \%-50 \%$ & Konsultatif \\
Sedang & $50 \%-75 \%$ & Partisipatif \\
Tinggi & $75 \%-100 \%$ & Delegatif \\
\hline \hline
\end{tabular}

Sumber : Halim (200\&)

Dari tabel 1(satu) diatas, dapat dijelaskan bahwa:

1. Pola hubungan instruktif, peranan pemerintah pusat lebih dominan dari Pendapatan Asli Daeraha kemandirian pemerintah daerah (daerah belum mampu melaksanakan otonomi daerah).

2. Pola hubungan konsultatif, campur tangan pemerintah pusat sudah mulai berkurang karena daerah dianggap sedikit lebih mampu melaksanakan otonomi daerah.

3. Pola hubungan partisipatif, campur tangan pemerintah pusat sudah banyak berkurang, karena tingkat kemandirian daerah mendekati tingkatan mampu melaksanakan urusan otonomi daerah.

4. Pola hubungan delegatif, yaitu campur tangan pemerintah pusat sudah tidak ada karena daerah telah benar-benar mampu dan mandiri dalam melaksanakan urusan otonomi daerah.

\section{Rasio Efektivitas Pendapatan Asli Daerah}

Rasio ini untuk mengukur tingkat pencapaian pemerintah daerah atas pendapatan asli daerah yang direncanakan. Rumus yang digunakan dalam menghitung Rasio Efektifitas Pandapatan Asli Daerah adalah:

$\begin{aligned} & \text { Rasio Efektifitas } \\ & \text { PAD }=\end{aligned} \frac{\text { Realisasi PAD }}{\text { Anggaran PAD }} \times 100 \%$
Sumber : Halim (2007)


Indikator evektifitas sebagai berikut:

Tabel 2: Tingkat Efektivitas Daerah

\begin{tabular}{ll}
\hline \hline Kemampuan Keuangan & Rasio Efektivitas (\%) \\
\hline \hline Sangat Efektif & $>100$ \\
Efektif & $90-100$ \\
Cukup Ekeftif & $80-90$ \\
Kurang Efektif & $60-80$ \\
Tidak Efktif & $0-60$ \\
\hline
\end{tabular}

Sumber: Halim (2007)

\section{Rasio Efisiensi Keuangan Daerah (REKD)}

Rasio ini untuk mengukur kemampuan daerah unruk memperoleh pendapatan dengan biaya yang telah dikeluarkan melalui perbandingan antara besarnya biaya yang dikeluarkan untuk memperoleh pendapatan dengan realisasi pendapatan yang diterima. Semakin besar hasilnya maka pemerintah daerah semakin efisien. Rumusnya sebagai berikut:

$$
\text { REKD }=\frac{\text { Realisasi Belanja Daerah }}{\text { Realisasi Pendapatan Daerah }} \times 100 \%
$$

Sumber : Halim (2007)

Indikator efisiensinya sebagai berikut:

Tabel 3: Kriteria Efisiensi Kinerja Keuangan

\begin{tabular}{ll}
\hline \hline Kemampuan Keuangan & Rasio Efektivitas (\%) \\
\hline \hline Tidak Efektif & $>100$ \\
Kurang Efisien & $90-100$ \\
Cukup Efisien & $80-90$ \\
Efisien & $60-80$ \\
Sangat Efisien & $<60$ \\
\hline \hline
\end{tabular}

Sumber: Halim (2007)

\section{METODE PENELITIAN}

Penelitian ini menggunakan metode deskriptif karena bertujuan untuk menginterpretasikan objek sesuai apa adanya. Hal ini seperti yang dijelaskan oleh Best, J. W., \& Kahn, J. V. (2016), bahwa penelitian deskriptif adalah salah satu jenis metode penelitian yang berusaha menggambarkan dan menginterpretasi objek sesuai dengan apa adanya. Penelitian ini menggambarkan bagaimana kinerja keuangan pemerintah daerah Provinsi Nusa Tenggara Timur dilihat dari sisi kemandirian, evektifitas, dan efisiensi. Selanjutnya akan diketahui Pendapatan Asli Daerah tingkatan mana kinerja keuangan Provinsi Nusa Tenggara Timur berdasarkan ketiga rasio tersebut. Karena itu, populasi sekaligus sampel pada penelitian ini adalah Pemerintah Provinsi Nusa Tenggara Timur. Data yang digunakan dalam penelitian ini adalah data sekunder, yang bersumber dari laporan keuang daerah Nusa Tenggara Timur. Selanjutnya, dari data yang tersedia, dilakukan analisa data. Tahapan analisis yang digunakan adalah adalah sebagai berikut : 
1. Menghitung Rasio Kemandirian Keuangan Daerah Provinsi Nusa Tenggara Timur

2. Menghitung Rasio Efektivitas pendapatan asli daerah provinsi Nusa Tenggara Timur

3. Menghitung Rasio Efisiensi Keuangan Daerah Provinsi Nusa Tenggara Timur

\section{HASIL PENELITIAN DAN PEMBAHASAN}

Analisis kinerja keuangan Provinsi Nusa Tenggara Timur Pendapatan Asli Daeraha penelitian ini dilakukan terhadap tingkat kemampuan dalam bidang keuangan di Badan Pengelola Keuangan Dan Aset Daerah Provinsi Nusa Tenggara Timur dalam kurun waktu 2012-2016. Rasio yang digunakan adalah rasio kemandirian, rasio efektifitas dan rasio efisiensi. Hasil dari perhitungan Rasio Kemandirian Keuangan Daerah dapat dilihat Pendapatan Asli Daeraha tabel berikut ini:

Tabel 4

Rasio Kemandirian Keuangan Daerah BPPKAD Provinsi NTT

Tahun 2012-2016

\begin{tabular}{|c|c|c|c|c|}
\hline $\begin{array}{c}\text { Tahun } \\
\text { Anggara } \\
\end{array}$ & PAD (Rp) & $\begin{array}{c}\text { Pendapatan Transfer atau } \\
\text { Dana Perimbangan }(\mathrm{Rp}) \\
\end{array}$ & RKKD & $\begin{array}{c}\text { Pola } \\
\text { Hubungan }\end{array}$ \\
\hline 2012 & 459.657 .187 .316 & 1.098 .619 .868 .970 & $41,84 \%$ & Konsultatif \\
\hline 2013 & 523.201 .203 .067 & 1.165 .848 .622 .793 & $44,88 \%$ & Konsultatif \\
\hline 2014 & 763.300 .806 .702 & 1.282 .745 .347 .275 & $59,51 \%$ & Partisipatif \\
\hline 2015 & 911.738 .759 .382 & 1.363 .026 .378 .197 & $66,89 \%$ & Partisipatif \\
\hline 2016 & 983.537 .687 .079 & 2.839 .657 .758 .567 & $34,64 \%$ & Konsultatif \\
\hline \multicolumn{3}{|c|}{ Rata-rata } & $49,55 \%$ & Konsultatif \\
\hline
\end{tabular}

Sumber data: BPPKAD Provinsi NTT 2017, diolah 2017

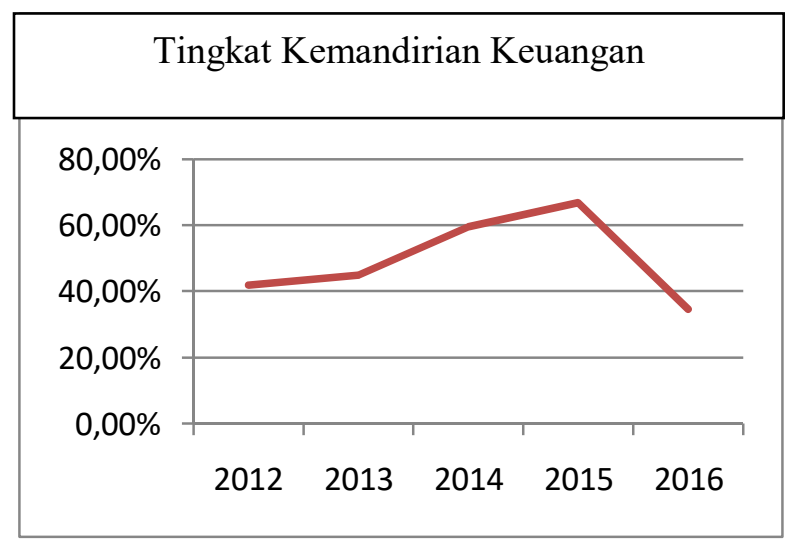

Sumber data diolah 2017

Gambar 1: Tingkat Kemandirian Keuangan Tahun 2012 - 2016

Berdasarkan tabel 4 (empat) dan gambar 2 (dua), dapat dijelaskan bahwa rasio kemandirian keuangan daerah Provinsi Nusa Tenggara Timur dari tahun 2012 sampai tahun 2015 mengalami peningkatan, bahkan Pendapatan Asli Daeraha tahun 2015 sampai ke level partisipatif. Yaitu campur tangan pemerintah pusat sudah banyak berkurang. Namun Pendapatan Asli Daeraha tahun 2016 mengalami penurunan sehingga level kemandiriannya kembali ke level konsultatif. Dari hasil wawancara 
dengan salah satu staf di Dinas tersebut diketahui penyebabnya adalah karena meningkatnya dana perimbangan seperti pos Dana Bagi Hasil, Dana Alokasi Umum dan Dana Alokasi Khusus.

Peningkatan level kemandirian keuangan daerah Provinsi Nusa Tenggara Timur dari tahun 2012 sampai tahun 2015 menggambarkan partisipasi masyarakat di Provinsi Nusa Tenggara Timur semakin meningkat, baik melalui Pajak Daerah dan Retribusi. Hal ini sekaligus menunjukkan bahwa perputaran uang di Provinsi Nusa Tenggara Timur semakin tinggi. Akan tetapi pemerintah pusat ingin lebih mempercepat pertumbuhan di daerah Provinsi Nusa Tenggara Timur sehingga Pendapatan Asli Daeraha tahun 2016 pendapatan transfer mengalami peningkatan yang tajam. Jika menggunakan data pendapatan transfer tahun 2012 sebagai tahun dasar, maka peningkatan pendapatan transfer Pendapatan Asli Daeraha tahun 2016 mencapai angka 158\%. Hasil dari perhitungan Rasio Efektivitas Pendapatan Asli Daerah dapat dilihat Pendapatan Asli Daeraha tabel berikut ini:

Tabel 5

Rasio Efektivitas PAD BPPKAD Provinsi NTT

Tahun 2012-2016

\begin{tabular}{|c|c|c|c|c|}
\hline Tahun & Realisasi (Rp) & Anggaran (Rp) & Persentase & $\begin{array}{l}\text { Tingkat } \\
\text { Efektif }\end{array}$ \\
\hline 2012 & 459.657 .187 .316 & 435.081 .956 .000 & $105 \%$ & Sangat Efektif \\
\hline 2013 & 523.201 .203 .067 & 476.687.746.171 & $109 \%$ & Sangat Efektif \\
\hline 2014 & 763.300 .806 .702 & 734.805 .391 .684 & $103 \%$ & Sangat Efektif \\
\hline 2015 & 911.738 .759 .382 & 872.546 .745 .800 & $104 \%$ & Sangat Efektif \\
\hline 2016 & 983.537 .687 .079 & 1.003 .412 .656 .000 & $98 \%$ & Efektif \\
\hline \multicolumn{3}{|c|}{ Rata-rata } & $104 \%$ & Sangat Efektif \\
\hline
\end{tabular}

Sumber data: BPPKAD Provinsi NTT, diolah 2017

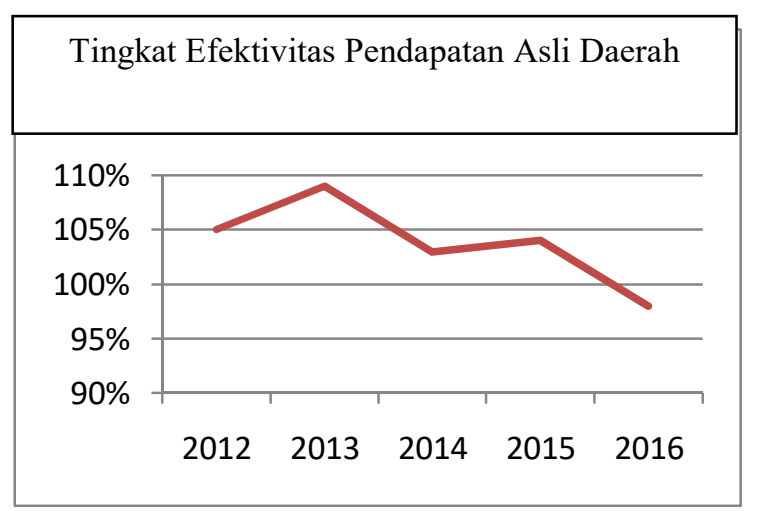

Sumber data diolah 2017

Gambar 2: Tingkat Efektifitas Pendapatan Asli Daerah Tahun 2012 - 2016

Berdasarkan tabel 5 (lima) dan gambar 2 (dua) dapat dijelaskan bahwa tingkat pencapaian realisasi pendapatan asli daerah terhadap anggaran untuk tahun 2012 sampai dengan 2015 adalah selalu sangat efektif atau melebihi yang ditargetkan. Hal ini dapat disebabkan karena semakin baiknya kinerja Badan Pengelola Keuangan Dan Aset 
Daerah dalam melakukan pemungutan dan penggalian potensi pajak daerah serta retribusi daerah. Juga ditunjang semakin tingginya tingkat perputaran perekonomian di Provinsi Nusa Tenggara Timur. Akan tetapi untuk tahun 2016 kembali mengalami penurunan karena banyak terjadi penunggakan pembayaran pajak daerah. Informasi ini diperoleh melalui wawancara dengan salah satu staf di Dinas tersebut.

Hasil dari perhitungan Rasio Efisiensi keuangan daerah dapat dilihat Pendapatan Asli Daeraha tabel berikut ini:

Tabel 6

Rasio Efisiensi Keuangan Daerah BPPKAD Provinsi NTT

Tahun 2012-2016

\begin{tabular}{|c|c|c|c|c|}
\hline Tahun & $\begin{array}{l}\text { Realisasi Belanja } \\
\text { Daerah (Rp) }\end{array}$ & $\begin{array}{l}\text { Realisasi Pendapatan } \\
\text { Daerah (Rp) }\end{array}$ & REKD & $\begin{array}{c}\text { Kemampuan } \\
\text { Keuangan }\end{array}$ \\
\hline 2012 & 2.164 .355 .591 .806 & 2.241 .542 .051 .286 & $96 \%$ & Kurang Efisien \\
\hline 2013 & 2.375 .665 .880 .320 & 2.387 .439 .508 .423 & $99 \%$ & Kurang Efisien \\
\hline 2014 & 2.688 .932 .744 .282 & 2.787 .513 .320 .677 & $96 \%$ & Kurang Efisien \\
\hline 2015 & 3.362 .435 .823 .752 & 3.243 .130 .476 .450 & $103 \%$ & Tidak Efisien \\
\hline 2016 & 3.694 .626 .516 .006 & 3.862.468.586.371 & $95 \%$ & Kurang Efisien \\
\hline \multicolumn{3}{|c|}{ Rata-rata } & $98 \%$ & Kurang Efisien \\
\hline
\end{tabular}

Sumber data: BPPKAD Provinsi NTT, diolah 2017

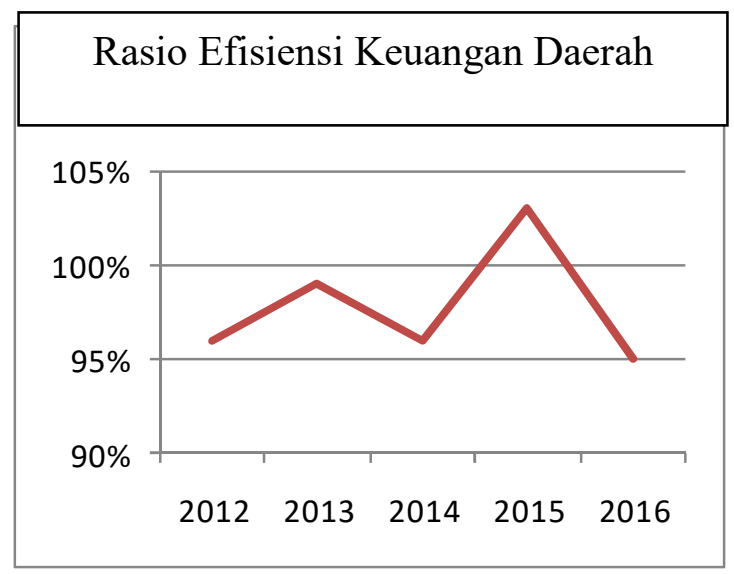

Sumber data diolah 2017

Gambar 3: Rasio Efiiensi Keuangan Daerah Tahun 2012 - 2016

Berdasarkan tabel 6 (enam) dan gambar 3 (tiga) dapat dijelaskan bahwa Efisiensi Keuangan Daerah Provinsi Nusa Tenggara Timur tahun 2012 sampai dengan tahun 2016 sebesar 98,6\% masih belum efisien. Karena besaran perolehan pendapatan atas belanja yang dilakukan masih tergolong kecil. Tingkat efisiensi keuangan Pemerintan Provinsi Nusa Tenggara Timur terutama untuk tahun 2015 paling rendah disebabkan karena meningkatnya pos-pos yang ada di Belanja Daerah seperti, belanja pegawai dikarenakan meningkatnya pegawai negri sipil dan dinas-dinas yang baru serta Belanja Bantuan Keuangan KePendapatan Asli Daeraha Provinsi/Kabupaten/Kota dan Pemerintahan Desa dan Partai Politik yang meningkat. Belanja ini diperlukan dalam rangka percepatan pelayanan kePendapatan Asli Daeraha masyarakat dan pembangunan daerah. 


\section{E. PENUTUP}

Dari hasil penelitian dan pembahasan diatas, dapat disimpulkan bahwa kemandirian keuangan Provinsi Nusa Tenggara Timur dari tahun 2012 sampai dengan 2015 terus mengalami peningkatan. Selain itu, tingkat pencapaian target pendapatan asli daerah provinsi Nusa Tenggara Timur dari tahun 2012 sampai dengan 2015 melebihi target, dan Pendapatan Asli Daeraha tahun 2016 tidak mencapai target. Untuk tingkat efisiensi, Provinsi Nusa Tenggara Timur belum efisien untuk tahun 2012 sampai dengan 2016. Hasil penelitian ini juga menunjukkan bahwa perekonomian masyarakat di Provinsi Nusa Tenggara Timur semakin membaik sehingga mendorong pencapaian target Pendapatan Asli Daerah.

Hasil penelitian ini juga dapat dikembangkan lebih lanjut dengan memasukkan variabel penelitian yang lain. Karena itu, kepada peneliti selanjutnya, disarankan untuk mengikutsertakan pertumbuhan jumlah penduduk, tingkat inflasi dan pemetaan kota seperti wilayah manasajakah yang memberikan kontribusi positif dan negatif terhadap keuangan Provinsi Nusa Tenggara Timur.

\section{DAFTAR PUSTAKA}

Best, J. W., \& Kahn, J. V. (2016). Research in education. Pearson Education India.

Halim, Abdul. 2007. Akuntansi Sektor Publik: Akuntansi Keuangan Daerah. Jakarta : Salemba Empat.

Kementerian Dalam Negeri. Permendagri Nomor 59/KDN/13-52/2007, tanggal 18 Desember 2007. Tentang Pedoman Pengelolaan Keuangan Daerah

Kementerian Dalam Negeri. Peraturan Pemerintah No. 24/KDN/32/2005, tanggal 13 juni 2005. Tentang Standar Akuntansi Pemerintahan

Kementerian Dalam Negeri. Peraturan Menteri Dalam Negeri Nomor 13/KDN/45-85/2006, 15 Mei 2006, tentang Pedoman Pengelolaan Keuangan Daerah.

MPR RI. Ketetapan Nomor IV/MPR/2000 tentang Rekomendasi Kebijakan Dalam Penyelenggaraan Otonomi Daerah

Pemerintah Pusat. Undang-Undang No.32 UU/2004/32/PP/1-5/2004, tanggal 30 Juni 2004 ayat 5. Tentang pemerintahan daerah.

Presiden Republik Indonesia. Tentang Standar Akuntansi Pemerintahan. Peraturan Pemerintah Republik Indonesia Nomor 71 tahun 2010

Purbowati, R., \& Mutiarni, R. (2017). PENGUNGKAPAN CORPORATE SOCIAL RESPONSIBILITY DITINJAU DARI KARAKTERISTIK PERUSAHAAN. JURNAL AKUNTANSI DAN BISNIS: Jurnal Program Studi Akuntansi, 3(2).

Sitinjak, N. D. (2016). Dampak Inflasi, Pertumbuhan Jumlah Pekerja, dan Pertumbuhan PDB per kapita Terhadap Penerimaan Pajak. Eksis: Jurnal Riset Ekonomi dan Bisnis, 11(2 Okt).

Utomo, L. P., Asyik, N. F., \& Hermanto, S. B (2017). Belanja Modal Memediasi Pengaruh Pendapatan Daerah Terhadap Pertumbuhan Ekonomi Daerah Otonomi Khusus. Jurnal Ilmiah Akuntansi dan Bisnis, 115-128. 